\title{
Dry Matter Intake is Decreased More by Abomasal Infusion of Unsaturated Free Fatty Acids than by Unsaturated Triglycerides*
}

\author{
N. B. Litherland, ${ }^{1}$ S. Thire, ${ }^{1}$ A. D. Beaulieu, ${ }^{1}{ }^{1} \dagger$ C. K. Reynolds, ${ }^{2} \neq$ \\ J. A. Benson, ${ }^{2} \S$ and J. K. Drackley ${ }^{1}$ \\ ${ }^{1}$ Department of Animal Sciences, University of Illinois, Urbana 61801 \\ ${ }^{2}$ Centre for Dairy Research, Department of Agriculture, \\ The University of Reading, Earley Gate, Reading, RG6 6AT, UK
}

\begin{abstract}
Previous experiments from our group have demonstrated that abomasal infusion of unsaturated free fatty acids (FFA) markedly decreases dry matter intake (DMI) in dairy cows. In contrast, experiments from other groups have noted smaller decreases in DMI when unsaturated triglycerides (TG) were infused postruminally. Our hypothesis was that unsaturated FFA would be more potent inhibitors of DMI than an equivalent amount of unsaturated TG. Four Holstein cows in late lactation were used in a single reversal design. Cows were fed a total mixed ration containing (DM basis) 23\% alfalfa silage, $23 \%$ corn silage, $40.3 \%$ ground shelled corn, and $10.5 \%$ soybean meal. Two cows received soy FFA (UFA; 0, 200, 400, $600 \mathrm{~g} / \mathrm{d}$ ) and 2 received soy oil (TG) in the same amounts; cows then were switched to the other lipid source. Cows were abomasally infused with each amount for 5-d periods. The daily amount of lipid was pulse-dosed in 4 equal portions at 0600, 1000, 1700, and $2200 \mathrm{~h}$; no emulsifiers were used and there was no sign of digestive disturbance. Both lipid sources linearly decreased DMI, with a significant interaction between lipid source and amount. Slope-ratio analysis indicated that UFA were about 2 times more potent in decreasing DMI than were TG. Decreased DMI led to decreased milk production. Milk fat content was increased linearly by lipid infusion. Milk fat yield decreased markedly for UFA infusion but was relatively
\end{abstract}

Received July 9, 2004.

Accepted November 15, 2004.

Corresponding author: James K. Drackley; e-mail: drackley@ uiuc.edu.

*Supported by USDA-CSREES Regional Research Funds appropriated to the Illinois Agricultural Experiment Station as part of project W-181, "Modifying milk fat composition for improved manufacturing qualities and consumer acceptability."

$\dagger$ Present address: Prairie Swine Centre, Inc., P. O. Box 21057, 2105 8th St. E., Saskatoon, SK, Canada S7H 5N9.

$\ddagger$ Present address: Department of Animal Sciences, The Ohio State University, OARDC, Wooster, OH 44696.

§Present address: 76 Iona Street, Edinburgh, UK EH6 8RW. unaffected by infusion of TG. Contents of short- and medium-chain fatty acids in milk fat decreased as the amount of either infusate increased. Contents of $\mathrm{C}_{18: 2}$ and $\mathrm{C}_{18: 3}$ in milk fat were increased linearly by abomasal infusion of either fat source; cis-9 $\mathrm{C}_{18: 1}$ was unaffected. Transfer of infused $\mathrm{C}_{18: 2}$ to milk fat was 35.6, 42.5 , and $27.8 \%$ for 200,400 , and $600 \mathrm{~g} / \mathrm{d}$ of UFA, and $34.3,39.6$, and $34.0 \%$ for respective amounts of TG. Glucagon-like peptide-1 (7-36) amide (GLP-1) concentration in plasma significantly increased as DMI decreased with increasing infusion amount of UFA or TG. Plasma concentration of cholecystokinin-octapeptide (CCK-8) was unaffected by lipid infusion. These results indicate that unsaturated FFA reaching the duodenum are more potent inhibitors of DMI than are unsaturated TG; the effect may be at least partially mediated by GLP-1.

(Key words: dry matter intake, dietary fat, unsaturated fatty acids, gut hormones)

Abbreviation key: CCK = cholecystokinin-octapeptide, FA = fatty acids, GLP-1 = glucagon-like peptide1 (7-36) amide, LCFA = long-chain fatty acids, $\mathbf{T G}=$ soybean oil (triglyceride) infused into the abomasum, UFA = soybean free fatty acids infused into the abomasum.

\section{INTRODUCTION}

Supplemental fat is often added to diets for lactating dairy cows in an attempt to increase energy intake during early lactation and promote positive energy balance. Contrary to this potential energetic benefit, supplemental dietary fat often decreases DMI, negating any energetic advantage of supplemental fat (Schauff and Clark, 1992; Schauff et al., 1992; Choi and Palmquist, 1996). If DMI is decreased more than can be compensated by the additional energy density of the diet, then $\mathrm{NE}_{\mathrm{L}}$ intake can be decreased (Schauff and Clark, 1992; Choi and Palmquist, 1996).

Understanding mechanisms by which long-chain fatty acids (LCFA) regulate feed intake is important to the evaluation of the use of dietary fat by lactating 
cows. Previous studies in our laboratory showed that abomasal infusion of unsaturated, but not saturated, FFA decreased DMI in lactating cows (Drackley et al., 1992; Christensen et al., 1994; Bremmer et al., 1998). The magnitude of decrease in DMI in these studies was much greater than when others infused much larger amounts of intact unsaturated oils postruminally (Gagliostro and Chilliard, 1991; Ottou et al., 1995). Bremmer et al. (1998) postulated that abomasal infusion of unsaturated FFA might interact with sensing mechanisms in the upper duodenum that lead to inhibition of feed intake, whereas abomasal infusion of unsaturated triglycerides would not because triglyceride hydrolysis occurs in the jejunum. Sensors for FFA appear to be more numerous in the upper duodenum (Woltman et al., 1995). Therefore, because FFA are released from triglycerides in the jejunum, distal to fatty acid sensing mechanisms, triglycerides reaching the duodenum should have less effect on DMI than FFA.

Choi and Palmquist (1996) suggested that decreased DMI in cows fed high fat diets is mediated by cholecystokinin (CCK). Cholecystokinin is secreted by enteroendocrine cells of the upper small intestine and regulates intake by vagal-neural sensory mechanisms or by reducing passage rate of digesta. If CCK is indeed a regulator of feed intake, then FFA infused into the abomasum should cause an increase in circulating concentration of CCK and a greater depression of DMI than triglyceride infused into the abomasum. In addition to CCK, numerous other peptides of gut origin, such as peptide YY and products of proglucagon processing [pancreatic glucagon, glicentin, oxyntomodulin, glucagon-like peptide 1 (GLP-1) or GLP-2], are potential mediators of the reduction in DMI observed in animals fed fat (Holst, 2000; Batterham and Bloom, 2003). Recent data in midlactation dairy cows have implicated GLP-1 as a factor controlling DMI during abomasal infusion of vegetable oil containing predominantly unsaturated LCFA (Benson and Reynolds, 2001).

Specific objectives of this study, therefore, were 1) to compare the effects of abomasal infusion of unsaturated FFA with those of unsaturated TG on DMI, milk yield and composition, and plasma metabolites and hormones, and 2) to determine possible mechanisms regulating DMI when intestinal supply of LCFA is increased.

\section{MATERIALS AND METHODS}

\section{Housing and Management of Cows}

All procedures were performed under protocols approved by the University of Illinois Laboratory Animal
Table 1. Ingredients and nutrient composition of the TMR (DM basis).

\begin{tabular}{lc}
\hline Composition & $(\%)$ \\
\hline Ingredient & \\
Alfalfa silage & 23.00 \\
Corn silage & 23.00 \\
Ground shelled corn & 40.32 \\
Soybean meal, 49\% CP & 10.50 \\
Sodium chloride & 0.25 \\
Mineral and vitamin mixture ${ }^{1}$ & 0.25 \\
Limestone & 0.63 \\
Dicalcium phosphate & 0.50 \\
Magnesium oxide & 0.20 \\
Sodium bicarbonate & 1.00 \\
Nutrient & 59.2 \\
DM & 93.0 \\
OM & 15.0 \\
CP & 26.6 \\
NDF & 16.8 \\
ADF & 1.66 \\
NE & ${ }^{2}$ Mcal/kg of DM
\end{tabular}

${ }^{1}$ Contains: $5.0 \% \mathrm{Mg}, 7.5 \% \mathrm{~K}, 10.0 \% \mathrm{~S}, 3.0 \% \mathrm{Zn}, 3.0 \% \mathrm{Mn}, 2.0 \% \mathrm{Fe}$, $0.5 \% \mathrm{Cu}, 0.025 \% \mathrm{I}, 0.015 \% \mathrm{Se}, 0.004 \% \mathrm{Co}, 2200 \mathrm{IU}$ of vitamin $\mathrm{A} / \mathrm{g}$, $660 \mathrm{IU}$ vitamin $\mathrm{D}_{3} / \mathrm{g}$, and $8 \mathrm{IU}$ of vitamin $\mathrm{E} / \mathrm{g}$.

${ }^{2}$ Calculated using equations from National Research Council (2001) and assuming an intake of 3 times maintenance.

Care Advisory Committee. Four multiparous Holstein cows (mean BW $=675 \mathrm{~kg}$ ) in late lactation were housed in individual stanchions and could stand and lie freely. Cows were bedded with sawdust on rubber-filled mattresses and were given daily access to a dry lot from 0430 to $0630 \mathrm{~h}$. Cows had been surgically fitted with ruminal cannulas (10.2 cm o.d.; Bar Diamond, Parma, ID) in a previous lactation. A TMR formulated to meet or exceed National Research Council recommendations for lactating cows (National Research Council, 1989,2001 ) was provided in individual feed bunks and water was available from individual water cups at all times. The TMR (Table 1) was fed twice daily at 1000 and $1700 \mathrm{~h}$ for ad libitum intake. Cows were milked twice daily at 0400 and $1500 \mathrm{~h}$.

\section{Experimental Design and Treatments}

The experiment was conducted as a single reversal design. Treatments consisted of abomasal infusions of soy FFA (UFA) or soy oil triglyceride (TG). Fatty acid (FA) composition of the 2 treatments was similar (Table 2). Soy FFA (Emery 618 Soya fatty acid) was graciously donated by the Henkel Corporation, Emery Division (Cincinnati, $\mathrm{OH}$ ). Soy oil was purchased from Archer Daniels Midland (Decatur, IL). Treatments were infused at increasing amounts of 0 (tap water only), 200, 400, and $600 \mathrm{~g} / \mathrm{d}$ for 5 -d periods at each amount. Infusion of treatments was based upon weight of lipid and not total FA content. Therefore, assuming 
Table 2. Fatty acid (FA) composition of diet and lipid infusates.

\begin{tabular}{lccc}
\hline & & \multicolumn{2}{c}{ Infusate } \\
\cline { 4 - 4 } FA & Diet & UFA & TG \\
\cline { 2 - 4 } & & $\mathrm{g} / 100 \mathrm{~g}$ of FA $)$ & \\
\cline { 2 - 4 } $\mathrm{C}_{12: 0}$ & 0.43 & $\mathrm{ND}^{1}$ & $\mathrm{ND}$ \\
$\mathrm{C}_{14: 0}$ & 0.19 & 0.10 & 0.08 \\
$\mathrm{C}_{16: 0}$ & 13.49 & 7.93 & 10.40 \\
$\mathrm{C}_{16: 1}$ & 0.15 & 0.12 & 0.09 \\
$\mathrm{C}_{17: 0}$ & $\mathrm{ND}$ & 0.01 & 0.10 \\
$\mathrm{C}_{18: 0}$ & 2.50 & 3.20 & 4.30 \\
$\mathrm{C}_{18: 1}$ cis-9 & 18.32 & 22.37 & 23.60 \\
$\mathrm{C}_{18: 1}$ cis-11 & 0.62 & $\mathrm{ND}$ & $\mathrm{ND}$ \\
$\mathrm{C}_{18: 2}$ & 41.03 & 54.13 & 52.4 \\
$\mathrm{C}_{18: 3}$ & 7.97 & 5.40 & 7.71 \\
$\mathrm{C}_{22: 0}$ & 0.43 & 0.15 & 0.33 \\
$\mathrm{C}_{24: 0}$ & 0.44 & $\mathrm{ND}$ & 0.11 \\
Unidentified FA & 14.43 & 6.59 & 0.88 \\
\hline
\end{tabular}

${ }^{1} \mathrm{ND}=$ Not detected .

that soy oil is $11 \%$ glycerol, the amount of FA infused for the TG treatment was $0,178,356$, and $534 \mathrm{~g} / \mathrm{d}$.

The abomasal infusion apparatus was assembled and placed in the abomasum as described by Drackley et al. (1992). Briefly, an infusion line (Tygon tubing, i.d. $4.8 \mathrm{~mm}$; Cole-Parmer Instrument Company, Vernon Hills, IL) attached to a polypropylene bottle was passed through the ruminal cannula and anchored into the abomasum with a rubber flange. Placement of the infusion line in the abomasum was checked daily. Treatments were infused with a $500-\mathrm{mL}$ syringe via Tygon tubing through the ruminal cannula plug into the abomasum. Treatments were infused in equal amounts delivered at 0600, 1000, 1700, and $2200 \mathrm{~h}$. Tap water was used to flush the abomasal tubing after each dosing.

A 5-d washout period was allowed before the crossover between treatments occurred, during which time tap water was infused to keep the infusion tubing from becoming plugged.

\section{Feed and Feed Refusals}

Feed offered and orts were measured and recorded daily to calculate daily DMI. Rations were adjusted weekly to reflect changes in DM content of forages and concentrate mixtures by drying each component overnight in an oven at $105^{\circ} \mathrm{C}$. Effects of treatments on DMI were calculated using data recorded from the last $3 \mathrm{~d}$ of each 5 -d period. Feed refusals from individual cows were weighed and sampled daily before the morning feeding. Samples of individual feed ingredients and TMR were collected for the last $3 \mathrm{~d}$ of each period. Samples of individual feedstuffs and TMR were dried at $55^{\circ} \mathrm{C}$ in an oven for $72 \mathrm{~h}$, and then ground through a $1-\mathrm{mm}$ screen in a Wiley mill (Arthur H.
Thomas, Philadelphia, PA). Samples of feeds, TMR, and orts were analyzed for DM, OM, Kjeldahl N (AOAC, 1995), ADF (Van Soest et al., 1991), and NDF, using heat-stable $\alpha$-amylase (Thermamyl 120L; Novo Nordisk Biochem, Franklinton, NC) and sodium sulfite (Van Soest et al., 1991).

\section{Milk Production and Composition}

Milk weights were recorded at each milking. Milk yield was calculated using data from the last $3 \mathrm{~d}$ of each period. Milk was sampled from each cow at each milking (p.m. and a.m.) on d 5 of each infusion period. Milk samples for each cow were composited in proportion to milk yield and were preserved with 2-bromo2-nitropropane-1,3-diol. Milk for the composite sample was warmed to aid in fat dispersion and inverted before subsampling. One aliquot of the composite sample was analyzed for contents of fat, protein, and lactose using midinfrared procedures (AOAC, 1995) on an automated analyzer (Foss 4000; Foss North America, Eden Prairie, MN) by Dairy Laboratory Services Inc. (Dubuque, IA). A separate aliquot from the composite milk sample was frozen at $-20^{\circ} \mathrm{C}$ for subsequent gas chromatographic analysis of FA composition. Milk samples for determination of FA were thawed and centrifuged to separate milk fat. Milk fat was transferred into a clean test tube, weighed, and FA were methylated using the procedure of Sukhija and Palmquist (1988). The resultant methyl esters of FA were separated on a Shimadzu 17A gas chromatograph equipped with an AOC 20i autosampler, a flame ionization detector, and a SP-2380 fused silica capillary column $(100 \mathrm{~m} \times 0.25 \mathrm{~mm}$ i.d.; $0.2-\mu \mathrm{m}$ phase film; Supelco, Bellefonte, PA). The initial temperature of $70^{\circ} \mathrm{C}$ was maintained for $4 \mathrm{~min}$; the oven temperature was increased at a rate of $8^{\circ} \mathrm{C} / \mathrm{min}$ to $180^{\circ} \mathrm{C}$, where it was held for $7 \mathrm{~min}$, and then increased at $5^{\circ} \mathrm{C} / \mathrm{min}$ to $220^{\circ} \mathrm{C}$. Total run time was $37 \mathrm{~min}$. The carrier gas was He at $21 \mathrm{~cm} / \mathrm{s}$ and the split ratio was 80:1. Fatty acids were identified by comparison of their retention times with those of known standards (Nu-Chek Prep, Elysian, MN; Matreya, Pleasant Gap, PA).

\section{Blood Sampling and Analysis}

On d 4 of each period, blood was sampled from the coccygeal vein of each cow $1 \mathrm{~h}$ before the a.m. feeding and $4 \mathrm{~h}$ after feeding. Blood samples were collected into evacuated test tubes (Vacutainer; Becton Dickinson, Rutherford, NJ) containing sodium heparin or EDTA as anticoagulants. Blood was centrifuged at 14,000 $\times$ $g$ for $15 \mathrm{~min}$ at $4^{\circ} \mathrm{C}$ to obtain plasma. The plasma was stored frozen $\left(-20^{\circ} \mathrm{C}\right)$ until analysis for concentrations 
of NEFA (NEFA C kit; Wako Chemicals, Dallas, TX), glucose (Glucose Trinder 500; Sigma Chemical Co., St. Louis, MO), triglyceride (kit number 339; Sigma Chemical Co.), and insulin (Coat-a-Count; Diagnostic Products, Los Angeles, CA). Concentrations of BHBA, cholesterol, and total protein were determined at the University of Illinois College of Veterinary Medicine diagnostic laboratory using automated analysis procedures. A separate aliquot of plasma $(2 \mathrm{~mL})$ containing $500 \mathrm{KIU}$ of aprotinin (Boehringer Mannheim Co., Indianapolis, IN) was used for analysis of CCK and GLP-1. Plasma concentrations of CCK-octapeptide and GLP-1 (7-36) amide were determined using double antibody radioimmunoassay as described by Benson and Reynolds (2001).

\section{Statistical Analysis}

Data collected during treatment infusions for each cow in each period were reduced to means for each infusion amount and were subjected to ANOVA using the GLM procedure of SAS as a reversal design with a split plot (SAS Institute, 2000). Two of the 4 cows were receiving bST at the beginning of the study. Given the expected increase in milk production due to administration of bST, cows were blocked by bST status. Model effects included cow, block, period, treatment (UFA vs. TG), amount, and the interaction of treatment $\times$ amount. To test for whole-plot effects (i.e., treatment), the type III mean square for block $\times$ treatment was used as the error term. In this design, the primary effects of interest were those of amount infused and the interaction treatment $\times$ amount infused, which were tested using the model residual error. Orthogonal contrasts were used to evaluate linear, quadratic, or cubic responses to amount of infusate. Contrasts also were used to partition the treatment $x$ amount interaction into single degree of freedom contrasts for interactions of treatment with the linear, quadratic, and cubic effects of increasing amount. Significance was declared at $P<0.05$.

\section{RESULTS AND DISCUSSION}

\section{DMI}

The DMI was decreased linearly by abomasal infusion of either UFA or TG (Table 3), with a significant interaction between amount of fat infused and fat source. Analysis of the slopes from regression of DMI on infusion amount (Figure 1) indicated that UFA were 2 times more potent in decreasing DMI than equivalent amounts of LCFA from TG. Abomasal infusion of unsaturated LCFA decreased DMI in other studies (Drackley et al., 1992; Christensen et al., 1994; Brem- mer et al., 1998; Benson et al., 2001). However, the maximal decrease in DMI associated with abomasal infusion of unsaturated LCFA observed in the present study $(-10.6 \mathrm{~kg} / \mathrm{d})$ was much greater than that observed in previous studies. Reductions in DMI compared with no fat infusion were $-1.8 \mathrm{~kg} / \mathrm{d}$ (Drackley et al., 1992), $-2.5 \mathrm{~kg} / \mathrm{d}$ (Christensen et al., 1994), or $-3.7 \mathrm{~kg} / \mathrm{d}$ (Bremmer et al., 1998) when $450 \mathrm{~g} / \mathrm{d}$ of soy FFA were infused into the abomasum, and $-0.9 \mathrm{~kg} / \mathrm{d}$ when $400 \mathrm{~g} / \mathrm{d}$ of a mixture of rapeseed and sunflower oil triglycerides was infused (Benson et al., 2001). In midlactation cows, DMI was decreased by $2.6 \mathrm{~kg} / \mathrm{d}$ when $1000 \mathrm{~g}$ of rapeseed oil was infused into the duodenum (Gagliostro and Chilliard, 1991).

The larger decrease of DMI in the current study compared with other studies using continuous postruminal infusion of unsaturated LCFA may be due, in part, to the pulse-dose method of delivery of FA to the abomasum. Ruminants naturally have a more continuous flow of digesta from the abomasum compared with the pulsatile flow that occurs in nonruminants. Perhaps the pulse dosage of fat caused a higher concentration of FA in the duodenum than did continuous infusion in previous studies and therefore amplified the reduction in DMI. Nutrient digestibility was not measured in the current study, but treatments did not cause diarrhea, and infusion of similar amounts of fat has not resulted in decreased nutrient digestibility in previous studies (Drackley et al., 1992; Christensen et al., 1994; Bremmer et al., 1998).

The physiological mechanism for the greater negative effect on DMI for UFA than TG remains speculative. Summaries by Bremmer et al. (1998) and Benson et al. (2001) of recent studies that have implemented postruminal infusion of LCFA established that polyunsaturated FFA have the most potent effect on DMI. Because the FA composition of the 2 treatments in the current study was similar, the main difference was the chemical structure (TG vs. FFA). Additionally, the amount infused was based on equal weight of triglyceride and FFA and not total FA, resulting in the UFA having approximately $10 \%$ more FA than the TG treatment due to the glycerol moiety in soybean oil. Bremmer et al. (1998) postulated that esterification of FA to glycerol may prohibit the sensing mechanism in the upper duodenum by which FFA inhibits DMI. Hydrolysis of triglycerides to FFA and glycerol occurs primarily in the jejunum. If FFA sensors are more prevalent in the upper duodenum, then triglycerides may not activate the sensing mechanism to the same extent as FFA. In rats, duodenal infusion of oleic acid rapidly decreased food intake in a dose-dependent manner (Woltman et al., 1995). Triolein, however, caused a slower response and was 4 times less potent than oleic 
Table 3. Dry matter intake, milk yield, and composition of milk.

\begin{tabular}{|c|c|c|c|c|c|c|}
\hline \multirow[b]{2}{*}{ Variable } & \multirow[b]{2}{*}{ Treatment $^{1}$} & \multicolumn{4}{|c|}{ Amount infused, g/d } & \multirow[b]{2}{*}{ SEM } \\
\hline & & 0 & 200 & 400 & 600 & \\
\hline \multirow[t]{2}{*}{ DMI, ${ }^{\mathrm{a}, \mathrm{b}} \mathrm{kg} / \mathrm{d}$} & UFA & 20.4 & 16.6 & 14.9 & 9.8 & \multirow[t]{2}{*}{0.95} \\
\hline & TG & 19.8 & 18.7 & 17.2 & 15.4 & \\
\hline \multirow[t]{2}{*}{ Milk, ${ }^{a} \mathrm{~kg} / \mathrm{d}$} & UFA & 22.3 & 21.4 & 17.9 & 13.0 & \multirow[t]{2}{*}{1.4} \\
\hline & TG & 21.8 & 20.9 & 18.7 & 18.0 & \\
\hline \multirow[t]{2}{*}{ Fat, $^{\text {a }} \%$} & UFA & 4.1 & 3.8 & 4.2 & 4.5 & \multirow[t]{2}{*}{0.03} \\
\hline & TG & 3.9 & 4.1 & 4.5 & 4.5 & \\
\hline \multirow[t]{2}{*}{ Fat, ${ }^{a, b} \mathrm{~kg} / \mathrm{d}$} & UFA & 0.92 & 0.82 & 0.75 & 0.59 & \multirow[t]{2}{*}{0.05} \\
\hline & TG & 0.85 & 0.84 & 0.86 & 0.80 & \\
\hline \multirow[t]{2}{*}{ Crude protein, $\%$} & UFA & 3.3 & 3.4 & 3.4 & 3.5 & \multirow[t]{2}{*}{0.07} \\
\hline & TG & 3.4 & 3.4 & 3.2 & 3.3 & \\
\hline \multirow[t]{2}{*}{ Crude protein, ${ }^{\mathrm{b}} \mathrm{kg} / \mathrm{d}$} & UFA & 0.75 & 0.72 & 0.62 & 0.46 & \multirow[t]{2}{*}{0.05} \\
\hline & TG & 0.73 & 0.70 & 0.60 & 0.58 & \\
\hline \multirow{2}{*}{ Lactose,$^{\mathrm{a}, \mathrm{b}} \%$} & UFA & 4.5 & 4.5 & 4.3 & 3.9 & \multirow[t]{2}{*}{0.13} \\
\hline & TG & 4.4 & 4.6 & 4.5 & 4.5 & \\
\hline \multirow{2}{*}{ Lactose,${ }^{a, b} \mathrm{~kg} / \mathrm{d}$} & UFA & 1.0 & 0.98 & 0.77 & 0.52 & \multirow[t]{2}{*}{0.08} \\
\hline & TG & 0.97 & 0.97 & 0.85 & 0.81 & \\
\hline \multirow[t]{2}{*}{ Total solids, \% } & UFA & 12.68 & 12.44 & 12.67 & 12.64 & \multirow[t]{2}{*}{0.24} \\
\hline & TG & 12.43 & 12.82 & 12.88 & 12.92 & \\
\hline \multirow[t]{2}{*}{ Total solids, ${ }^{\mathrm{a}, \mathrm{b}} \mathrm{kg} / \mathrm{d}$} & UFA & 2.84 & 2.66 & 2.72 & 1.66 & \multirow[t]{2}{*}{0.16} \\
\hline & TG & 2.71 & 2.65 & 2.43 & 2.31 & \\
\hline \multirow{2}{*}{ Milk urea $\mathrm{N},{ }^{\mathrm{a}} \mathrm{mg} / \mathrm{dL}$} & UFA & 12.57 & 18.72 & 20.69 & 24.20 & \multirow[t]{2}{*}{2.06} \\
\hline & TG & 12.05 & 17.45 & 18.33 & 20.42 & \\
\hline
\end{tabular}

${ }^{\mathrm{a}}$ Linear effect of amount, $P<0.05$.

${ }^{\mathrm{b}}$ Treatment $\times$ linear effect of amount, $P<0.05$.

${ }^{1} \mathrm{UFA}=$ Free FA from soy oil infused into the abomasum; TG = soy oil infused into the abomasum.

acid in suppressing intake. Data from the current study support the conclusion that esterified LCFA are less potent suppressors of DMI than FFA of similar composition.

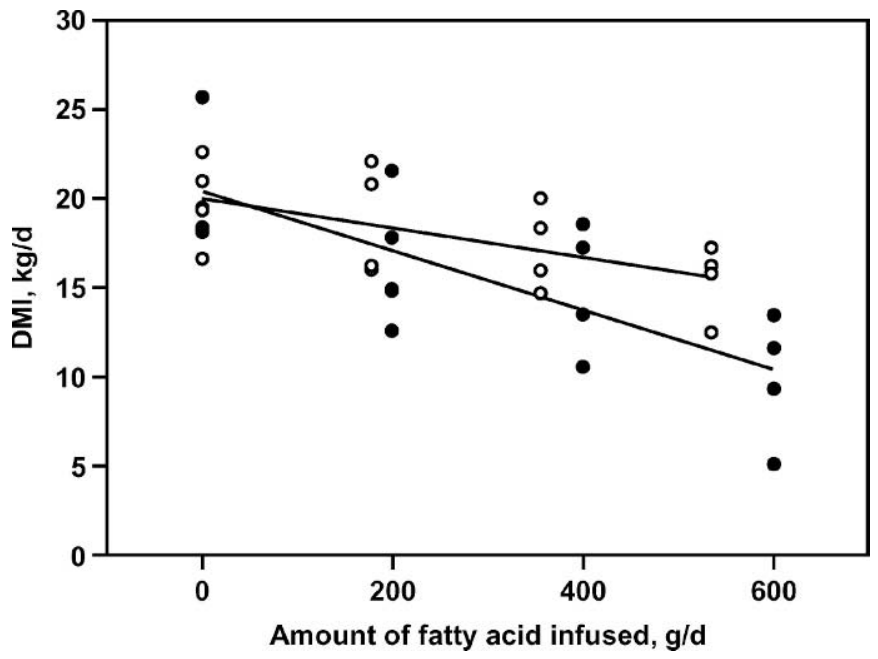

Figure 1. Relationship between DMI (y; kg/d) and the amount of soy FFA (closed symbols) and fatty acids from triglycerides (open symbols) infused into the abomasum $(\mathrm{x} ; \mathrm{g} / \mathrm{d}): \mathrm{y}=-0.016 \mathrm{x}+20.4\left(\mathrm{r}^{2}=\right.$ $0.57)$ for soy FFA; $y=-0.008 x+20.0\left(r^{2}=0.36\right)$ for soy TG. Each point represents the mean DMI of individual cows during each collection period.

\section{Milk Production and Composition}

Milk production was decreased linearly by both UFA and TG treatments (Table 3). Infusion of UFA depressed milk production to a greater numerical extent than infusion of TG, but the interaction of treatment $\times$ amount infused was not significant. Decreased milk yield was likely due to reduced nutrient intake. If infusions did not alter diet digestibility, calculated $\mathrm{NE}_{\mathrm{L}}$ intake (including the LCFA infused) was $32.9,32.5$, 31.3 , and $29.8 \mathrm{Mcal} / \mathrm{d}$ for TG, and 33.8, 28.9, 27.4, and $20.3 \mathrm{Mcal} / \mathrm{d}$ for UFA at $0,200,400$, and $600 \mathrm{~g} / \mathrm{d}$ infusion amounts, respectively. Infusions of fat, therefore, failed to increase $\mathrm{NE}_{\mathrm{L}}$ due to the subsequent reduction in DMI with infusion of either UFA or TG. Intake of $\mathrm{NE}_{\mathrm{L}}$ may have been affected by the relatively short time of adaptation to infusions compared with other studies (Gagliostro and Chilliard, 1991). Reductions in milk yield in the current study were greater than those observed in previous studies when LCFA were infused into the abomasum (Drackley et al., 1992; Christensen et al., 1994; LaCount et al., 1994; Bremmer et al., 1998; Benson et al., 2001) or duodenum (Gagliostro and Chilliard, 1991).

The content of fat in milk (Table 3) was increased linearly $(P<0.05)$ by either UFA or TG infusion. Changes in milk fat have been variable when LCFA were infused postruminally. Variability in milk fat 
response may be partially due to stage of lactation or the extent to which DMI was affected by infusion of fat. No changes in milk fat content or yield were observed with LCFA infusion by Drackley et al. (1992) and Christensen et al. (1994). Milk fat percentages increased with infusions of soy FFA and soy FFA high in palmitic acid, but this increase was associated with a decrease in milk volume with no change in milk fat secreted (Bremmer et al., 1998). Abomasal infusion of mostly long-chain unsaturated FA as triglycerides increased milk fat percentage and yield in midlactation cows (Benson et al., 2001). Milk fat yield was decreased markedly by UFA infusion in the present study, but was relatively unaffected by infusion of TG (treatment $\times$ linear amount, $P<0.05$ ). Reduced milk fat yield likely was associated with reduced milk volume.

Milk protein content (Table 3) was not changed by lipid infusion, but yield of milk protein was decreased linearly by UFA (treatment $\times$ linear amount, $P<0.05$ ). Data from many studies have shown that postruminal infusion of fat or feeding diets supplemented with fat have a negative effect on milk protein concentration (DePeters and Cant, 1992; Wu and Huber, 1994). The absence of a negative milk protein response in the present study may have been due to an adequate supply of dietary and microbial amino acids reaching the small intestine or to the short duration of the trial.

Milk lactose content and production (Table 3) were reduced linearly as amount of UFA increased (treatment $\times$ linear amount, $P<0.05$ ). Total solids content was not affected by lipid infusion; total solids yield decreased linearly, with the extent of decrease greater for UFA (treatment $\times$ linear amount, $P<0.05$ ). Milk urea $\mathrm{N}$ content was linearly increased by both treatments. Although milk nonprotein $\mathrm{N}$ typically increases when fat is supplemented to the diet (DePeters and Cant, 1992), the reasons remain unclear. Most theories have revolved around events in the rumen (DePeters and Cant, 1992), which do not seem likely here given that FA were supplemented postruminally and cows consumed a TMR. Previous studies in which FA were infused abomasally did not result in differences in either MUN or ruminal ammonia concentrations (Christensen et al., 1994; Bremmer et al., 1998).

\section{Composition of Milk Fat}

Data in Table 4 indicate that infusion of UFA and TG significantly altered the FA composition of milk fat (Table 2). Milk fat contents of $\mathrm{C}_{4: 0}, \mathrm{C}_{6: 0}$, and $\mathrm{C}_{18: 1}$ were unaffected by lipid infusion. Contents of $\mathrm{C}_{8: 0}$, $\mathrm{C}_{10: 0}, \mathrm{C}_{12: 0}, \mathrm{C}_{14: 0}, \mathrm{C}_{15: 0}, \mathrm{C}_{16: 0}, \mathrm{C}_{16: 1}$, and $\mathrm{C}_{17: 0}$ decreased linearly $(P<0.05)$ as increasing amounts of either UFA or TG were infused. Decreases in the short- and medium-chain FA in milk as more LCFA were supplied postruminally are consistent with known effects of blood-derived LCFA on de novo FA synthesis in the mammary gland (Palmquist et al., 1993). Content of $\mathrm{C}_{18: 0}$ was decreased by UFA but not by TG (treatment $\times$ linear amount, $P<0.05$ ). Amounts of $\mathrm{C}_{18: 2}$ (linear amount, $P<0.05$ ) and $\mathrm{C}_{18: 3}$ (treatment $\times$ linear amount, $P<0.05$ ) in milk fat were increased by UFA and TG infusion as expected given their enhanced provision from the intestinal tract (Palmquist et al., 1993). Similar changes in milk FA composition were observed by Drackley et al. (1992) and Christensen et al. (1994) when soy FFA were infused into the abomasum.

Yields (Table 5) of $\mathrm{C}_{4: 0}$ and $\mathrm{C}_{6: 0}$ in milk fat were not changed by fat infusion. Yields of $\mathrm{C}_{8: 0}, \mathrm{C}_{10: 0}, \mathrm{C}_{12: 0}, \mathrm{C}_{14: 0}$, $\mathrm{C}_{15: 0}, \mathrm{C}_{16: 0}, \mathrm{C}_{16: 1}$, and $\mathrm{C}_{17: 0}$ were decreased linearly by either UFA or TG infusion. Yields of $\mathrm{C}_{16: 0}, \mathrm{C}_{18: 0}$, and $\mathrm{C}_{18: 1}$ decreased more when UFA was infused (treatment $\times$ linear amount, $P<0.05$ ). Yields of $\mathrm{C}_{18: 2}$ (linear amount, $P<0.05$ ) and $\mathrm{C}_{18: 3}$ (treatment $\times$ linear amount, $P<0.05$ ) increased when either lipid source was infused. Effects of infusates on milk FA yields reflected the combined influences of changes in FA profile (Table 4) as described above and the general decrease of milk fat yield as the amount of lipid infused increased (Table 3).

Transfer efficiencies were calculated to assess incorporation of infused FA into milk fat. Transfer efficiencies were calculated by subtracting the yield of FA during control infusions from that when cows were infused with either UFA or TG divided by the amount of abomasally infused LCFA. The estimates therefore combine effects due to digestion, absorption, and metabolism of LCFA. An estimated 35.6, 42.5, and 27.8\% of infused $\mathrm{C}_{18: 2}$ for UFA infusions and 34.3, 39.6, and $34.0 \%$ of infused $\mathrm{C}_{18: 2}$ for $\mathrm{TG}$ infusions was transferred to milk fat during infusions of 200,400 , and $600 \mathrm{~g} / \mathrm{d}$, respectively. These calculations assume that provision of LCFA from the control diet remains the same; this is not the case when treatments decrease DMI and thus transfer is underestimated. Transfer efficiencies from this study were slightly lower than those reported by Drackley et al. (1992), who estimated that $46 \%$ of infused $\mathrm{C}_{18: 2}$ was transferred into milk fat following infusion of $450 \mathrm{~g} / \mathrm{d}$ of a mix of mostly unsaturated LCFA. Differences might relate to different modes of infusion (pulse-dose of nonemulsified lipids vs. continuous infusion of emulsified lipids) and differences in the effects of infusions on DMI and milk yield.

\section{Plasma Metabolites and Insulin}

Preprandial concentrations of glucose, insulin, NEFA, triglyceride, BHBA, and total protein did not 
Table 4. Contents of individual fatty acids (FA) in milk.

\begin{tabular}{|c|c|c|c|c|c|c|}
\hline \multirow[b]{2}{*}{ FA } & \multirow[b]{2}{*}{ Treatment $^{1}$} & \multicolumn{4}{|c|}{ Amount infused, g/d } & \multirow[b]{2}{*}{ SEM } \\
\hline & & 0 & 200 & 400 & 600 & \\
\hline & & & - $(\mathrm{g} /$ & fat) & - & \\
\hline \multirow[t]{2}{*}{$\mathrm{C}_{4: 0}$} & UFA & 3.33 & 3.95 & 3.71 & 3.41 & 0.34 \\
\hline & TG & 3.65 & 3.74 & 3.59 & 3.54 & \\
\hline \multirow{2}{*}{$\mathrm{C}_{6: 0}$} & UFA & 1.91 & 1.81 & 2.12 & 2.07 & 0.31 \\
\hline & TG & 1.64 & 2.23 & 2.05 & 2.05 & \\
\hline \multirow[t]{2}{*}{$\mathrm{C}_{8: 0}{ }^{\mathrm{a}}$} & UFA & 1.49 & 1.56 & 1.31 & 1.32 & 0.07 \\
\hline & TG & 1.60 & 1.47 & 1.22 & 1.22 & \\
\hline \multirow{2}{*}{$\mathrm{C}_{10: 0^{\mathrm{a}}}$} & UFA & 3.39 & 3.47 & 2.89 & 3.15 & 0.21 \\
\hline & TG & 3.36 & 3.37 & 2.66 & 2.71 & \\
\hline \multirow[t]{2}{*}{$\mathrm{C}_{12: 0}{ }^{\mathrm{a}}$} & UFA & 3.84 & 3.82 & 3.12 & 3.44 & 0.26 \\
\hline & TG & 4.12 & 3.79 & 2.86 & 2.97 & \\
\hline \multirow[t]{2}{*}{$\mathrm{C}_{14: 0^{\mathrm{a}}}$} & UFA & 11.12 & 10.31 & 8.84 & 9.00 & 0.47 \\
\hline & TG & 11.20 & 10.07 & 8.33 & 8.17 & \\
\hline \multirow{2}{*}{$\mathrm{C}_{15: 0^{\mathrm{a}}}$} & UFA & 1.17 & 0.91 & 0.72 & 0.64 & 0.03 \\
\hline & TG & 1.17 & 0.96 & 0.78 & 0.69 & \\
\hline \multirow[t]{2}{*}{$\mathrm{C}_{16: 0^{\mathrm{a}}}$} & UFA & 31.15 & 26.06 & 22.81 & 22.61 & 1.31 \\
\hline & TG & 30.58 & 26.32 & 23.60 & 23.43 & \\
\hline \multirow[t]{2}{*}{$\mathrm{C}_{16: 1^{\mathrm{a}}}$} & UFA & 1.62 & 1.21 & 0.97 & 0.99 & 0.02 \\
\hline & TG & 1.65 & 1.18 & 1.01 & 0.93 & \\
\hline \multirow[t]{2}{*}{$\mathrm{C}_{17: 0^{\mathrm{a}}}$} & UFA & 0.55 & 0.47 & 0.38 & 0.36 & 0.01 \\
\hline & TG & 0.51 & 0.39 & 0.44 & 0.36 & \\
\hline \multirow{2}{*}{$\mathrm{C}_{18: 0}^{\mathrm{ab}}$} & UFA & 9.72 & 10.02 & 8.11 & 6.21 & 0.72 \\
\hline & TG & 9.35 & 10.87 & 10.57 & 9.03 & \\
\hline \multirow[t]{2}{*}{$\mathrm{C}_{18: 1}$} & UFA & 20.96 & 20.66 & 20.86 & 19.26 & 1.00 \\
\hline & TG & 21.30 & 21.64 & 23.18 & 20.85 & \\
\hline \multirow[t]{2}{*}{$\mathrm{C}_{18: 2^{\mathrm{a}}}$} & UFA & 2.74 & 8.09 & 16.36 & 19.30 & 1.09 \\
\hline & TG & 2.68 & 6.96 & 12.70 & 16.55 & \\
\hline \multirow[t]{2}{*}{$\mathrm{C}_{18: 3^{\mathrm{ab}}}$} & UFA & 0.40 & 0.93 & 1.59 & 1.91 & 0.11 \\
\hline & TG & 0.36 & 0.97 & 1.78 & 2.36 & \\
\hline
\end{tabular}

${ }^{\mathrm{a}}$ Linear effect of amount, $P<0.05$.

${ }^{\mathrm{b}}$ Treatment $\times$ linear effect of amount, $P<0.05$.

${ }^{1} \mathrm{UFA}=$ Free FA from soy oil infused into the abomasum; TG = soy oil infused into the abomasum.

differ between treatments or among infusion amounts (Table 6). Preprandial total protein tended $(P<0.06)$ to be affected by an interaction of treatment and the quadratic effect of increasing amount infused; concentrations were lower during infusion of UFA and higher during TG infusion than during control infusions. A similar tendency was detected for preprandial cholesterol (treatment $\times$ linear effect of amount, $P<0.06$ ). These tendencies may have resulted from the greater negative impact of UFA on DMI. Postprandial concentrations (Table 7) of glucose, insulin, triglyceride, BHBA, and total protein were not affected by treatments, but NEFA in plasma increased $(P<0.05)$ as amount of either LCFA source increased. Abomasal infusion of LCFA elicited no change in plasma NEFA concentration in 2 studies (Christensen et al., 1994; Bremmer et al., 1998). However, concentrations of NEFA were increased by infusing LCFA into the abomasum or duodenum (Rindsig and Schultz, 1974; Gagliostro et al., 1991) and by feeding fat-supplemented diets (Smith et al., 1978; Wrenn et al., 1978; Drackley, 1999). The postprandial concentration of cholesterol (Table 7$)$ was lower $(P<0.05)$ in cows infused with
UFA than for those infused with TG. Similar changes in plasma cholesterol were observed in other studies when unsaturated FFA were infused into the abomasum (Christensen et al., 1994; LaCount et al., 1994). Lower plasma cholesterol may reflect lower DMI.

\section{Gut Hormones in Plasma}

No difference was observed in pre- or postprandial concentrations of CCK in plasma (Table 8). Concentrations of CCK measured in our study were considerably lower than those reported by Choi and Palmquist (1996). Maximum CCK concentrations were $18.0 \mathrm{pmol} /$ $\mathrm{L}$ for infusion of $400 \mathrm{~g} / \mathrm{d}$ of UFA in the present study, compared with more than $80 \mathrm{pmol} / \mathrm{L}$ when $9 \%$ calcium salts of LCFA were fed in the study by Choi and Palmquist (1996). The comparatively lower CCK concentration observed in our study might be due to differences in the assay system and antibody, a lower level of fat supplementation, the different method of fat delivery (abomasal infusion vs. dietary), or average stage of lactation. Cows used in the current study were in late lactation $($ mean $=250$ DIM), whereas cows used by 
Table 5. Yields of individual fatty acids (FA) in milk.

\begin{tabular}{|c|c|c|c|c|c|c|}
\hline \multirow[b]{2}{*}{ FA } & \multirow[b]{2}{*}{ Treatment $^{1}$} & \multicolumn{4}{|c|}{ Amount infused, g/d } & \multirow[b]{2}{*}{ SEM } \\
\hline & & 0 & 200 & 400 & 600 & \\
\hline \multirow{2}{*}{$\mathrm{C}_{4: 0}$} & UFA & 28.7 & 32.5 & 29.2 & 20.2 & 4.0 \\
\hline & TG & 31.8 & 31.3 & 31.2 & 28.8 & \\
\hline \multirow[t]{2}{*}{$\mathrm{C}_{6: 0}$} & UFA & 16.6 & 15.6 & 17.0 & 12.5 & 2.9 \\
\hline & TG & 14.6 & 19.0 & 18.4 & 17.0 & \\
\hline \multirow{2}{*}{$\mathrm{C}_{8: 0^{\mathrm{a}}}$} & UFA & 14.3 & 13.2 & 10.8 & 7.9 & 0.98 \\
\hline & TG & 13.9 & 12.6 & 11.1 & 10.2 & \\
\hline \multirow{2}{*}{$\mathrm{C}_{10: 0^{\mathrm{a}}}$} & UFA & 32.7 & 29.8 & 24.1 & 19.1 & 2.3 \\
\hline & TG & 31.7 & 29.0 & 24.6 & 22.7 & \\
\hline \multirow[t]{2}{*}{$\mathrm{C}_{12: 0}{ }^{\mathrm{a}}$} & UFA & 36.8 & 32.7 & 25.7 & 20.7 & 2.5 \\
\hline & TG & 35.9 & 32.7 & 26.3 & 24.3 & \\
\hline \multirow{2}{*}{$\mathrm{C}_{14: 0^{\mathrm{a}}}$} & UFA & 105.9 & 86.1 & 70.2 & 53.3 & 6.2 \\
\hline & TG & 96.6 & 85.4 & 75.2 & 66.4 & \\
\hline \multirow{2}{*}{$\mathrm{C}_{15: 0}{ }^{\mathrm{a}}$} & UFA & 10.9 & 7.5 & 5.6 & 3.8 & 0.54 \\
\hline & TG & 9.9 & 8.1 & 6.7 & 5.4 & \\
\hline \multirow{2}{*}{$\mathrm{C}_{16: 0}^{\mathrm{ab}}$} & UFA & 289.0 & 215.1 & 174.2 & 132.0 & 15.0 \\
\hline & TG & 258.9 & 220.4 & 204.4 & 185.0 & \\
\hline \multirow{2}{*}{$\mathrm{C}_{16: 1^{\mathrm{a}}}^{\mathrm{a}}$} & UFA & 13.9 & 9.2 & 6.8 & 5.5 & 0.6 \\
\hline & TG & 13.1 & 9.3 & 8.2 & 7.0 & \\
\hline \multirow[t]{2}{*}{$\mathrm{C}_{17: 0}^{\mathrm{ab}}$} & UFA & 4.9 & 3.8 & 2.9 & 2.1 & 0.3 \\
\hline & $\mathrm{TG}$ & 4.3 & 4.1 & 3.8 & 2.9 & \\
\hline \multirow{2}{*}{$\mathrm{C}_{18: 0} \mathrm{ab}$} & UFA & 88.5 & 81.3 & 61.6 & 36.3 & 8.3 \\
\hline & TG & 79.8 & 89.2 & 87.8 & 74.4 & \\
\hline \multirow[t]{2}{*}{$\mathrm{C}_{18: 1}{ }^{\mathrm{ab}}$} & UFA & 187.9 & 164.5 & 150.5 & 111.4 & 13.6 \\
\hline & TG & 178.5 & 179.5 & 191.4 & 162.7 & \\
\hline \multirow{2}{*}{$\mathrm{C}_{18: 2}{ }^{\mathrm{a}}$} & UFA & 24.7 & 63.2 & 116.7 & 115.1 & 10.3 \\
\hline & TG & 22.9 & 58.8 & 106.0 & 129.8 & \\
\hline \multirow[t]{2}{*}{$\mathrm{C}_{18: 3}{ }^{\mathrm{ab}}$} & UFA & 3.7 & 7.5 & 11.6 & 11.4 & 1.2 \\
\hline & TG & 3.2 & 8.2 & 14.9 & 18.4 & \\
\hline
\end{tabular}

${ }^{a}$ Linear effect of amount, $P<0.05$.

${ }^{\mathrm{b}}$ Treatment $\times$ linear effect of amount, $P<0.05$.

${ }^{1} \mathrm{UFA}=$ Free FA from soy oil infused into the abomasum; TG = soy oil infused into the abomasum.

Choi and Palmquist (1996) were in midlactation (115 DIM) However, Benson and Reynolds (2001) found no difference in arterial plasma CCK concentration between early lactation (55 DIM) and midlactation (111 DIM) cows abomasally infused with LCFA.
Abomasal infusion of $400 \mathrm{~g} / \mathrm{d}$ of mostly unsaturated LCFA significantly reduced DMI, but did not affect splanchnic metabolism or arterial concentration of CCK (Benson and Reynolds, 2001). In another study, high fat diets containing calcium salts of LCFA fed

Table 6. Preprandial concentrations of metabolites and insulin in plasma.

\begin{tabular}{|c|c|c|c|c|c|c|}
\hline \multirow[b]{2}{*}{ Component } & \multirow[b]{2}{*}{ Treatment $^{1}$} & \multicolumn{4}{|c|}{ Amount infused, g/d } & \multirow[b]{2}{*}{ SEM } \\
\hline & & 0 & 200 & 400 & 600 & \\
\hline \multirow[t]{2}{*}{ Glucose, mg/dL } & UFA & 71.1 & 68.3 & 65.9 & 62.8 & \multirow[t]{2}{*}{4.8} \\
\hline & TG & 66.4 & 71.8 & 74.2 & 63.2 & \\
\hline \multirow[t]{2}{*}{ Insulin, $\mu \mathrm{IU} / \mathrm{mL}$} & UFA & 15.6 & 12.7 & 16.1 & 12.6 & \multirow[t]{2}{*}{1.6} \\
\hline & TG & 16.3 & 10.7 & 13.6 & 12.8 & \\
\hline \multirow{2}{*}{ NEFA, $\mu \mathrm{eq} / \mathrm{L}$} & UFA & 91.5 & 109.8 & 104.8 & 132.8 & \multirow[t]{2}{*}{27.9} \\
\hline & TG & 95.2 & 94.0 & 100.3 & 89.0 & \\
\hline \multirow[t]{2}{*}{ Triglyceride, mg/dL } & UFA & 7.6 & 12.7 & 9.5 & 10.1 & \multirow[t]{2}{*}{0.89} \\
\hline & TG & 9.3 & 11.2 & 11.0 & 10.8 & \\
\hline \multirow[t]{2}{*}{ BHBA, mg/dL } & UFA & 3.3 & 3.8 & 4.2 & 4.5 & \multirow[t]{2}{*}{0.43} \\
\hline & TG & 3.6 & 3.7 & 3.2 & 4.2 & \\
\hline \multirow[t]{2}{*}{ Total protein, g/dL } & UFA & 9.0 & 8.4 & 8.4 & 8.5 & \multirow[t]{2}{*}{0.20} \\
\hline & TG & 8.7 & 8.7 & 8.9 & 8.5 & \\
\hline \multirow[t]{2}{*}{ Cholesterol, mg/dL } & UFA & 152.1 & 138.3 & 138.8 & 134.0 & \multirow[t]{2}{*}{8.44} \\
\hline & TG & 148.3 & 152.3 & 168.3 & 162.8 & \\
\hline
\end{tabular}

${ }^{1} \mathrm{UFA}=$ Free FA from soy oil infused into the abomasum; TG = soy oil infused into the abomasum. 
Table 7. Postprandial concentrations of metabolites and insulin in plasma.

\begin{tabular}{|c|c|c|c|c|c|c|}
\hline \multirow[b]{2}{*}{ Component } & \multirow[b]{2}{*}{ Treatment $^{1}$} & \multicolumn{4}{|c|}{ Amount infused, g/d } & \multirow[b]{2}{*}{ SEM } \\
\hline & & 0 & 200 & 400 & 600 & \\
\hline \multirow[t]{2}{*}{ Glucose, mg/dL } & UFA & 69.3 & 69.9 & 60.1 & 65.3 & \multirow[t]{2}{*}{5.1} \\
\hline & TG & 62.9 & 69.6 & 65.8 & 66.9 & \\
\hline \multirow[t]{2}{*}{ Insulin, $\mu \mathrm{IU} / \mathrm{mL}$} & UFA & 11.9 & 8.7 & 16.7 & 14.4 & \multirow[t]{2}{*}{2.1} \\
\hline & TG & 11.9 & 10.3 & 15.3 & 11.9 & \\
\hline \multirow[t]{2}{*}{$\mathrm{NEFA},{ }^{\mathrm{a}} \mu \mathrm{eq} / \mathrm{L}$} & UFA & 73.8 & 86.0 & 117.3 & 155.0 & \multirow[t]{2}{*}{20.0} \\
\hline & $\mathrm{TG}$ & 96.3 & 92.5 & 101.0 & 106.0 & \\
\hline \multirow[t]{2}{*}{ Triglyceride, mg/dL } & UFA & 9.4 & 11.3 & 10.1 & 11.9 & \multirow[t]{2}{*}{1.9} \\
\hline & TG & 8.6 & 13.6 & 11.2 & 12.8 & \\
\hline \multirow[t]{2}{*}{ BHBA, mg/dL } & UFA & 5.6 & 4.0 & 5.7 & 5.2 & \multirow[t]{2}{*}{0.73} \\
\hline & TG & 5.4 & 5.1 & 4.1 & 5.6 & \\
\hline \multirow[t]{2}{*}{ Total protein, g/dL } & UFA & 8.9 & 8.8 & 9.0 & 8.7 & \multirow[t]{2}{*}{0.14} \\
\hline & TG & 8.7 & 8.7 & 8.9 & 8.5 & \\
\hline \multirow[t]{2}{*}{ Cholesterol, ${ }^{\mathrm{b}} \mathrm{mg} / \mathrm{dL}$} & UFA & 153.6 & 143.3 & 150.5 & 137.3 & \multirow[t]{2}{*}{6.9} \\
\hline & $\mathrm{TG}$ & 148.8 & 149.8 & 171.0 & 165.0 & \\
\hline
\end{tabular}

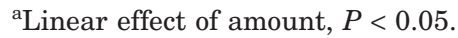

${ }^{\mathrm{b}}$ Treatment $\times$ linear effect of amount, $P<0.05$.

${ }^{1} \mathrm{UFA}=$ FA from soy oil infused into the abomasum; TG = soy oil infused into the abomasum.

to dairy cattle linearly decreased DMI and linearly increased plasma CCK in a sample taken before feeding, but the effect was not maintained after feeding (Choi et al., 2000). Additionally, administration of a CCK antagonist (MK-239) to heifers fed a high fat diet increased DMI by $92 \%$ compared with vehicle injection during a 2-h period after feeding (Choi et al., 2000), but there was no effect of MK-239 on total daily DMI. Although plasma CCK concentration in the current study did not correspond to the results of Choi and Palmquist (1996), CCK data were comparable with that noted by Furuse et al. (1991), in which plasma CCK concentrations ranged from 5 to $7 \mathrm{pmol} / \mathrm{L}$. Data collected by Furuse et al. (1991) were from 3 cows fed a high forage diet with no supplemental fat. In mice, CCK is known to be a relatively short-term regulator of feed intake, with increases in circulating CCK reaching peak concentration around $30 \mathrm{~min}$ after meal consumption (Moran et al., 1992). If CCK is a shortterm regulator of feed intake in dairy cattle then the frequency of blood sampling in the current study may have been inadequate to detect a response. In addition, ad libitum-fed dairy cows have more frequent, smaller meals; thus, if CCK is a regulator of meals it may have less impact on daily DMI than with limit feeding.

In contrast to plasma concentration of CCK, both pre- and postprandial concentrations of GLP-1 increased linearly with increasing amount of UFA or TG infused (Table 8). The concentration of plasma GLP1 increased as DMI decreased, suggesting a possible direct or indirect role of GLP-1 in feed intake regulation. Abomasal infusion of $400 \mathrm{~g} / \mathrm{d}$ of mostly unsaturated triglycerides significantly increased arterial concentration of GLP-1 in the study by Benson and Reynolds (2001); plasma concentrations of GLP-1 observed in that study were similar to those observed in the

Table 8. Preprandial and postprandial concentrations of the gut hormones cholecystokinin (CCK) and glucagon-like peptide-1 (GLP-1) in plasma.

\begin{tabular}{|c|c|c|c|c|c|c|}
\hline \multirow[b]{2}{*}{ Hormone } & \multirow[b]{2}{*}{ Treatment $^{1}$} & \multicolumn{4}{|c|}{ Amount infused, g/d } & \multirow[b]{2}{*}{ SEM } \\
\hline & & 0 & 200 & 400 & 600 & \\
\hline \multicolumn{7}{|l|}{$\mathrm{CCK}, \mathrm{pmol} / \mathrm{L}$} \\
\hline \multirow[t]{2}{*}{ Preprandial } & UFA & 13.6 & 14.0 & 18.0 & 14.1 & \multirow[t]{2}{*}{2.68} \\
\hline & TG & 10.0 & 11.4 & 11.9 & 11.7 & \\
\hline \multirow[t]{2}{*}{ Postprandial } & UFA & 11.4 & 9.4 & 12.7 & 12.4 & \multirow[t]{2}{*}{1.90} \\
\hline & TG & 9.8 & 10.3 & 13.2 & 12.5 & \\
\hline \multicolumn{7}{|l|}{ GLP-1, pmol/mL } \\
\hline \multirow[t]{2}{*}{ Preprandial $^{\mathrm{a}}$} & UFA & 0.023 & 0.024 & 0.034 & 0.050 & \multirow[t]{2}{*}{0.006} \\
\hline & TG & 0.024 & 0.030 & 0.032 & 0.039 & \\
\hline \multirow[t]{2}{*}{ Postprandial $^{\mathrm{a}}$} & UFA & 0.020 & 0.028 & 0.038 & 0.061 & \multirow[t]{2}{*}{0.007} \\
\hline & TG & 0.024 & 0.032 & 0.034 & 0.044 & \\
\hline
\end{tabular}

${ }^{\text {a}}$ Linear effect of amount, $P<0.05$.

${ }^{1} \mathrm{UFA}=$ Free FA from soy oil infused into the abomasum; TG = soy oil infused into the abomasum. 
Table 9. Pearson correlation coefficients among selected variables. ${ }^{1}$

\begin{tabular}{lccllll}
\hline & DMI & $\begin{array}{l}\text { Preprandial } \\
\text { CCK }\end{array}$ & $\begin{array}{l}\text { Postprandial } \\
\text { CCK }\end{array}$ & $\begin{array}{l}\text { Preprandial } \\
\text { GLP-1 }\end{array}$ & $\begin{array}{l}\text { Postprandial } \\
\text { GLP-1 }\end{array}$ & $\begin{array}{l}\text { Preprandial } \\
\text { insulin }\end{array}$ \\
\hline Preprandial CCK & -0.04 & & & & & \\
& $(0.82)$ & & & & & \\
Postprandial CCK & -0.09 & -0.02 & & & \\
Preprandial GLP-1 & $-0.63)$ & $(0.89)$ & & & & \\
& $(<0.39$ & 0.29 & $(0.106)$ & $(0.22)$ & & \\
Postprandial GLP-1 & -0.51 & 0.26 & 0.20 & 0.95 & & \\
& $(<0.05)$ & $(0.15)$ & $(0.27)$ & $(<0.05)$ & -0.41 & \\
Preprandial insulin & 0.34 & 0.22 & -0.09 & -0.35 & $(<0.05)$ & 0.55 \\
& $(0.06)$ & $(0.23)$ & $(0.616)$ & $(<0.05)$ & 0.16 & $(<0.05)$ \\
\hline
\end{tabular}

${ }^{1}$ Number in parentheses below each correlation coefficient $(r)$ is the probability that $|r|>0$.

current study. In nonruminants, GLP-1 has been shown to have numerous effects that may impact appetite and DMI, including appetite-suppressing effects on the hypothalamus, reduced gut motility, and increased insulin synthesis and secretion (Holst, 2000). The increases in circulating concentrations of GLP-1 in response to abomasal LCFA infusion in the present study, as well as the study of Benson and Reynolds (2001), suggest that GLP-1 secretion is responsive to LCFA supply to the small intestine in lactating dairy cows. In addition, these data suggest that GLP- 1 is a potential mediator of the reduced DMI observed when unsaturated LCFA were infused.

To identify associations between DMI during LCFA infusions and concentrations of CCK, GLP-1, and insulin in plasma, we computed correlation coefficients (Table 9). The DMI was negatively correlated with pre- $(\mathrm{r}=-0.39)$ and postprandial $(\mathrm{r}=-0.51)$ plasma concentrations of GLP-1. The greater correlation for postprandial GLP-1 may be associated with the combined effect of both feeding and pulse-dose infusion of LCFA compared with preprandial values. In contrast, pre- and postprandial plasma concentrations of CCK were not significantly correlated with DMI. These correlations confirm that increasing plasma concentrations of GLP-1 were highly related to differences in DMI due to abomasal infusion of LCFA; therefore, GLP-1 is likely a hormone regulating DMI, whereas CCK is not under these conditions. To better visualize the relationship between DMI and postprandial plasma concentrations of GLP-1, variables were analyzed using simple linear regression (Figure 2). Regression analysis indicated that the negative relationship with DMI explained $27 \%$ of the variation in postprandial plasma concentration of GLP-1.

Preprandial insulin concentration was weakly correlated $(P<0.06)$ with DMI, but postprandial insulin was not. Preprandial insulin concentrations were neg- atively correlated with both pre- and postprandial GLP-1 concentrations; postprandial insulin was not associated with GLP-1 concentrations. These data suggest that in dairy cows, GLP-1 may not have the same incretin effects on insulin secretion as that observed in nonruminants (Holst, 2000).

\section{Infusion Technique}

Abomasal infusion provides a method of delivery of unsaturated LCFA to the small intestine by circumventing the rumen, thus preventing biohydrogenation of unsaturated LCFA. Previous studies (Drackley et al., 1992; Christensen et al., 1994; LaCount et al., 1994; Bremmer et al., 1998) implemented continuous infusion of a mixture of partially emulsified FFA. The current study evaluated the use of pulse-dose infusions

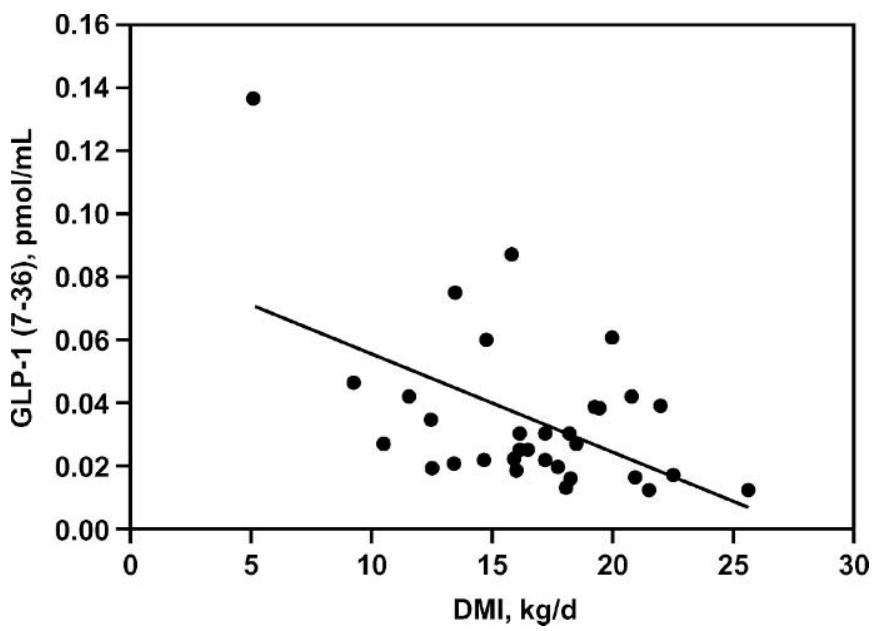

Figure 2. Relationship between DMI (x; kg/d) and glucagon-like peptide 1 (GLP-1) $(\mathrm{y} ; \mathrm{pmol} / \mathrm{mL}): \mathrm{y}=-0.0031 \mathrm{x}+0.087\left(\mathrm{r}^{2}=0.27\right)$. Each point represents the mean DMI of individual cows during each collection period. 
of LCFA as either FFA or triglycerides 4 times daily. Observation of DMI depression without the use of infusion carriers suggests that meat solubles and Tween 80 used in previous studies (Drackley et al., 1992; Christensen et al., 1994, LaCount et al., 1994; Bremmer et al., 1998) were not a factor in the observed DMI responses in those studies. No diarrhea was observed as a consequence of infusing nonemulsified oils in the current study. Although FA digestibility was not measured, incorporation of unsaturated LCFA from the infusates into milk fat indicated that LCFA were absorbed with reasonable efficiency. The system used here is much simpler and less time-consuming than continuous infusion of emulsified lipids, and thus may have advantages for certain experimental objectives.

\section{CONCLUSIONS}

Our results confirmed that abomasal infusion of unsaturated FFA more potently suppresses DMI than an equivalent amount of unsaturated triglycerides. Milk yield was decreased and milk fat composition was altered by infusion of UFA and TG. These results help to reconcile differences in the magnitude of response between experiments that have used postruminal infusion of unsaturated FFA and those that have infused intact oils. Moreover, our results highlight the potential of feeding strategies or fat supplements that increase postruminal supply of unsaturated FFA to have detrimental effects on DMI.

Decreased DMI due to abomasal infusion of unsaturated FFA may be a result of triggering sensing mechanisms in the small intestine that lead to increased plasma concentrations of GLP-1. Plasma concentration of CCK was not affected by abomasal infusion of either UFA or TG. Our data indicate that the amount of unsaturated FFA passing to the small intestine may increase circulating concentration of GLP-1 in a dosedependent manner; increased concentrations of GLP1 were related to decreased DMI. Additional research is warranted to explore the relationship of GLP-1 and its function in regulating feed intake when supplemental fat is fed to lactating dairy cows.

\section{REFERENCES}

Association of Official Analytical Chemists. 1995. Official Methods of Analysis. 16th ed. AOAC, Arlington, VA.

Batterham, R. L., and S. R. Bloom. 2003. The gut hormone Peptide YY regulates appetite. Ann. N. Y. Acad. Sci. 994:162-168.

Benson, J. A., and C. K. Reynolds. 2001. Effects of abomasal infusion of long-chain fatty acids on splanchnic metabolism of pancreatic and gut hormones in lactating dairy cows. J. Dairy Sci. $84: 1488-1500$.
Benson, J. A., C. K. Reynolds, D. J. Humphries, S. M. Rutter, and D. E. Beever. 2001. Effects of abomasal infusion of long-chain fatty acids on intake, feeding behavior and milk production in dairy cows. J. Dairy Sci. 84:1182-1191.

Bremmer, D. R., L. D. Ruppert, J. H. Clark, and J. K. Drackley. 1998. Effects of chain length and unsaturation of fatty acid mixtures infused into the abomasum of lactating dairy cows. J. Dairy Sci. 81:176-188.

Choi, B. R., and D. L. Palmquist. 1996. High fat diets increase plasma cholecystokinin and pancreatic polypeptide, and decrease plasma insulin and feed intake in lactating dairy cows. J. Nutr. 126:2913-2919.

Choi, B. R., D. L. Palmquist, and M. S. Allen. 2000. Cholecystokinin mediates depression of feed intake in dairy cattle fed high fat diets. Domest. Anim. Endocrinol. 19:159-175.

Christensen, R. A., J. K. Drackley, D. W. LaCount, and J. H. Clark. 1994. Infusion of four long-chain fatty acid mixtures into the abomasum of lactating dairy cows. J. Dairy Sci. 77:1052-1069.

DePeters, E. J., and J. P. Cant. 1992. Nutritional factors influencing the nitrogen composition of bovine milk: A review. J. Dairy Sci. 75:2043-2070.

Drackley, J. K. 1999. Biology of dairy cows during the transition period: The final frontier? J. Dairy Sci. 82:2259-2273.

Drackley, J. K., T. H. Klusmeyer, A. M. Trusk, and J. H. Clark. 1992. Infusion of long-chain fatty acids varying in saturation and chain length into the abomasum of lactating dairy cows. J. Dairy Sci. 75:1517-1526.

Furuse, M., S. I. Yang, Y. H. Choi, N. Kawamura, A. Takahashi, and J. Okumura. 1991. A note on plasma cholecystokinin concentration in dairy cows. Anim. Prod. 53:123-125.

Gagliostro, G., and Y. Chilliard. 1991. Duodenal rapeseed oil infusion in early and midlactation cows. 2 . Voluntary intake, milk production, and composition. J. Dairy Sci. 74:499-509.

Gagliostro, G., Y. Chilliard, and M. J. Davicco. 1991. Duodenal rapeseed oil infusion in early and midlactation cows. 3. Plasma hormones and mammary apparent uptake of metabolites. J. Dairy Sci. 74:1893-1903.

Holst, J. J. 2000. Gut hormones as pharmaceuticals. From enteroglucagon to GLP-1 and GLP-2. Reg. Peptides 93:45-51.

LaCount, D. W., J. K. Drackley, S. O. Laesch, and J. H. Clark. 1994. Secretion of oleic acid in milk fat in response to abomasal infusions of canola or high oleic sunflower fatty acids. J. Dairy Sci. 77:1372-1385.

Moran, T. H., P. J. Ameglio, G. J. Schwartz, and P. R. Mchugh. 1992. Blockade of type A, not type B, CCK receptors attenuates satiety actions of exogenous and endogenous CCK. Am. J. Physiol. 262:R46-R50.

National Research Council. 1989. Nutrient Requirements of Dairy Cattle. 6th rev. ed. Natl. Acad. Sci., Washington, DC.

National Research Council. 2001. Nutrient Requirements of Dairy Cattle. 7th rev. ed. Natl. Acad. Sci., Washington, DC.

Ottou, J. F., M. Doreau, and Y. Chilliard. 1995. Duodenal infusion of rapeseed oil in midlactation cows. 6. Interaction with niacin on dairy performance and nutritional balance. J. Dairy Sci. 78:1345-1352.

Palmquist, D. L., A. D. Beaulieu, and D. M. Barbano. 1993. Feed and animal factors influencing milk fat composition. J. Dairy Sci. 76:1753-1771.

Rindsig, R. B., and L. H. Schultz. 1974. Effects of abomasal infusions of safflower oil or elaidic acid on blood lipids and milk fat in dairy cows. J. Dairy Sci. 57:1459-1466.

SAS Institute. 2000. The SAS System of Windows. Release 8.1 (TS1 MO). SAS Institute, Inc., Cary, NC.

Schauff, D. J., and J. H. Clark. 1992. Effects of feeding diets containing calcium salts of long-chain fatty acids to lactating dairy cows. J. Dairy Sci. 75:2990-3002.

Schauff, D. J., J. H. Clark, and J. K. Drackley. 1992. Effects of feeding lactating dairy cows diets containing extruded soybeans and calcium salts of long-chain fatty acids. J. Dairy Sci. 75:3003-3019. 
Smith, N. E., W. L. Dunkley, and A. A. Franke. 1978. Effects of feeding protected tallow to dairy cows in early lactation. J. Dairy Sci. 61:747-756.

Sukhija, P. S., and D. L. Palmquist. 1988. Rapid method for determination of total fatty acid content and composition of feedstuffs and feces. J. Agric. Food Chem. 36:1202-1206.

Van Soest, P. J., J. B. Robertson, and B. A. Lewis. 1991. Methods for dietary fiber, neutral detergent fiber, and nonstarch polysaccharides in relation to animal nutrition. J. Dairy Sci. 74:3583-3597.
Woltman, T., D. Castellanos, and R. Reidelberger. 1995. Role of cholecystokinin in the anorexia produced by duodenal delivery of oleic acid in rats. Am. J. Physiol. 269:R1420-R1433.

Wrenn, T. R., J. Bitman, R. A. Waterman, J. R. Weyant, D. L. Wood, L. L. Strozinski, and N. W. Hooven, Jr. 1978. Feeding protected and unprotected tallow to lactating cows. J. Dairy Sci. 61:49-58.

Wu, Z., and J. T. Huber. 1994. Relationship between dietary fat supplementation and milk protein concentration: A review. Livest. Prod. Sci. 39:141-155. 